\title{
The effect of ICTs on academic achievement: the Conectar Igualdad programme in Argentina
}

\author{
María Verónica Alderete and Maria Marta Formichella
}

ABSTRACT

The objective of this paper is to determine the "premium," in terms of academic achievement, that accrues to student beneficiaries of the Conectar Igualdad programme with respect to students not participating in the programme. For this purpose, the propensity score matching (PSM) method is used. The programme is described, as is the theoretical framework used to define the explanatory factors of academic achievement, which may affect the likelihood of participation in the programme. The target population are 15-year-old students in Argentina. The study draws on data from the 2012 round of Programme for the International Student Assessment (PISA) tests. The findings indicate that there are statistically significant differences in average academic achievement associated with participation in the Conectar Igualdad programme. Department of Economics (UNs). mvalderete@iiess-conicet.gob.ar.

María Marta Formichella is a researcher at the Institute of Social and Economic Research of South - IIEss (National Council of Scientific and Technical Research (CONICET), National University of the South - UNs), Department of Economics (Uns). mformichella@iiess-conicet.gob.ar. 


\section{I}

\section{Introduction}

In recent decades, education systems have participated in the sweeping changes brought about by the global dissemination of new information and communications technologies (ICTS). The exponential growth of information that is available anywhere to anybody and the ability to access and share this information regardless of the user's physical location have transformed the way in which people work, organize, socialize, create, participate in public forums and use their free time (Castells, 1999, in Claro and others, 2011).

Incorporating ICTs has become a very important priority in the education sector. These technologies can contribute to universal access to education, equality in instruction, quality in teaching and learning and the professional development of teachers, as well as to more efficient management and administration of education systems. Thus, they are essential to achieving more egalitarian societies (UNESCO, 2014).

The analysis of ICTs in the education sector is closely tied to the objectives of quality, equity and efficiency (Sunkel and Trucco, 2012). Integrating these technologies into schools means rethinking both the way in which these institutions are set up and the practices that derive from that configuration. Consideration must also be given to curriculum development and the work of teachers and students in the classroom (Consejo Federal de Educación, 2010).

The repercussions of ICTs can be seen in the education policy agendas of every country in Latin America (SITEAL, 2014), which have implemented various programmes for the mass rollout of these technologies. These models are

\section{II}

\section{State of the art}

ICTs spread opportunities for communication within educational institutions and beyond them, creating new learning possibilities for students, including those for whom the formal education system cannot provide coverage (Becta, 2007). Participating in the information society means not only having access to new technologies but also acquiring the skills needed to use them. Thus, not standard across the region but rather vary from one country to the next depending on the national context. In Argentina, the Conectar Igualdad ("Connecting Equality") programme stands out as a type of digital inclusion policy at the federal level.

The availability of country-level information on the use of ICTs in secondary schools is not exhaustive. The ICT questionnaire that was included as a supplement to the Programme for International Student Assessment (PISA) was administered only in a small group of countries in Latin America (Chile, Panama, Trinidad and Tobago and Uruguay); Argentina was not part of this group.

The objective of this paper is to identify the "premium," in terms of academic achievement, accruing to the student beneficiaries of the Conectar Igualdad programme, compared with their non-beneficiary peers. To this end, the propensity score matching (PSM) technique is used, drawing on data from the PISA test administered in Argentina in 2012. The paper is structured as follows. Section II describes the state of the art in research on the role of ICTs in education and gives an overview of ICT-implementation initiatives, especially in countries in Latin America, with special emphasis on the case of Argentina. Section III presents the analytical framework that describes the theoretical and empirical findings with respect to the effects of ICTS on academic achievement. Section IV explains the propensity score matching methodology that was applied and presents the data and variables. Lastly, Section V discusses the results and presents final considerations.
ICTs are an important instrument for promoting inclusive practices (Claro, 2011).

Access to ICTS in the education sector is related to the availability of material resources in the school (Sunkel and Trucco, 2012). Computers enable time and cost savings, faster results, distance learning, assessment of student achievement based on exam scores and 
monitoring of classroom progress, among other benefits (Witte and Rogge, 2014; Terzis and Economides, 2011; Parshall and other, 2002).

ICTs can be used to bring training and learning opportunities within reach of a large number of people at a low marginal cost. The savings in travel time and the economies of scale that are achieved lower the cost of learning and lead to cost efficiency (Maguire and Zhang, 2007).

The new ICTs give teachers and students faster and better access to information, reducing the degree of obsolescence of information and making more efficient use of the various information sources available online (Lara and Duart, 2005).

It should be noted that effective use of ICTs in teaching and learning is largely determined by the attitude of school administrators and teachers, who can guarantee that access is accompanied by appropriate use of the resources. However, there is more interest -both in Argentina and in other countries - in using computers for educational purposes, or computer-aided instruction (CAI), than in computer skills training (CST) (Angrist and Lavy, 2002).

In Latin America, the Economic Commission for Latin America and the Caribbean (ECLAC) is working together with the European Union to implement the project "Alliance for the Information Society 2 - Inclusive Policy Dialogue and Exchange of Experiences (@ LIs2).” This project is based on the understanding that ICTs are not an end in themselves but rather a means to achieve development objectives and, in the education sector, to achieve educational objectives.

The Plan of Action for the Information Society in Latin America and the Caribbean (elaC 2010), which establishes a set of strategies to promote the use of ICTS for development, has identified education as a priority for equitable development in the information society (Sunkel and Trucco, 2010).

The World Bank has developed strategies to help the countries of Latin America take advantage of the opportunities created by ICTs in education, providing equipment and facilities, teacher training, distance learning, digital literacy and assessment, among other benefits. Likewise, the Inter-American Development Bank (IDB) is advancing initiatives that incorporate these technologies into education to improve the quality of student achievement (Claro, 2011).

Thus far, the main focus of the efforts made by school systems in Latin America has been to install adequate technology infrastructure in schools on an equitable basis and ensure that students and teachers acquire basic literacy in their use (Sunkel, Trucco and Möller, 2011).
Claro and others (2011) show that the region's school systems have succeeded in partially offsetting inequalities in access to ICTs in the home by expanding coverage at school. Nevertheless, the likelihood that a student will have frequent access to ICTs remains higher in the home than at school, owing to a low ratio of computers to students and lack of Internet connection. In both settings, one of the most frequent uses of ICTS is for schoolwork.

Argentina has lost some of its edge in recent years and is now ranked third in terms of computer access, with Uruguay and Chile in the lead. In terms of Internet access, Brazil, Uruguay and Chile are top-ranked, and Argentina is in fourth position (see figure 1).

According to data provided by PISA for 2009, the gap between Latin America and the OECD in the percentage of 15 -year-old students with access to a computer is very similar in magnitude to the gap in access to the Internet (around two-fold) and has remained unchanged over time. Much of the region's youth do not have access to technology at home. However, there has been progress in terms of the number of students per computer and the percentage of computers with Internet access in schools (Claro and others, 2011).

A number of programmes for the mass rollout of ICTS have been implemented, under various models, in Latin American countries. Table 1 lists the programmes that have been implemented in some of the region's countries.

In Argentina, the National Education Law (No. 26,206) incorporates the topic of ICTs under the provisions on national education policy, promotion of educational equality and quality of education. The political importance of a school that supports the integration of ICTs is stated explicitly in Articles 7 and 8 of the law, which establish that "the State guarantees access for all citizens to information and knowledge as a central instrument of participation in a process of economic growth and social justice" and "education shall provide the necessary opportunities to develop and strengthen the full education of individuals throughout their lives and promote in each student the capacity to set the course of his/her own life, based on the values of liberty, peace, solidarity, equality, respect for diversity, justice, accountability and the common good." In recent years, ICT initiatives in Argentine schools have clearly been on the rise. ${ }^{1}$

1 Initiatives have been underway in Argentina since the 1990s to install computers and other devices, establish connectivity, provide teacher training and prepare digital resources, with varying scope and success. Although these initiatives have played an important role in familiarizing the educational community with ICTs, they have represented only modest progress and yielded unsatisfactory results in terms of coverage, training and educational resources (UNICEF, 2013a) 
FIGURE 1

\section{Latin America and the Caribbean (seven countries): percentage of 15-year-old students with computer and Internet access in the home, 2000-2009}

\section{A. With computer access}

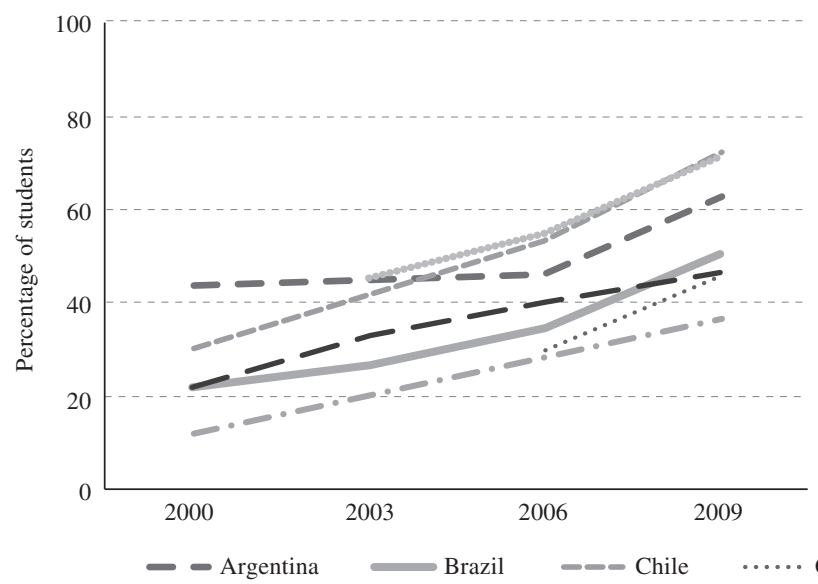

B. With Internet access

Source: M. Claro and others, "Aporte del sistema educativo a la reducción de las brechas digitales. Una mirada desde las mediciones PISA," Project Document (LC/W.456), Santiago, Economic Commission for Latin America and the Caribbean (ECLAC), 2011.

TABLE 1

ICT and Education Programmes in Latin America

\begin{tabular}{|c|c|c|c|}
\hline Country & Programme name & Participating agency & Scope \\
\hline Argentina & Conectar Igualdad & Ministry of Education & $\begin{array}{l}\text { Secondary education; } \\
\text { teacher training }\end{array}$ \\
\hline \multirow[t]{3}{*}{ Brazil } & EDUCOM programme & \multirow[t]{3}{*}{ Ministry of Education (MEC) } & \multirow{3}{*}{$\begin{array}{l}\text { Basic education (early childhood, } \\
\text { primary and secondary education) }\end{array}$} \\
\hline & $\begin{array}{l}\text { National Educational Technology } \\
\text { Programme (PROINFO) }\end{array}$ & & \\
\hline & UCA programme & & \\
\hline \multirow[t]{3}{*}{ Chile } & ICTS in the Classroom & \multirow[t]{3}{*}{ Ministry of Education (MINEDUC) } & \multirow[t]{3}{*}{ Basic education } \\
\hline & Enlaces programme & & \\
\hline & $\begin{array}{l}\text { Technologies Plan for Quality Education } \\
\text { (Plan TEC) }\end{array}$ & & \\
\hline \multirow[t]{3}{*}{ Colombia } & "Computadores para educar" & \multirow{3}{*}{$\begin{array}{l}\text { Ministry of National } \\
\text { Education (MEN) }\end{array}$} & \multirow{3}{*}{$\begin{array}{l}\text { Pre-school, primary, secondary } \\
\text { and post-secondary }\end{array}$} \\
\hline & $\begin{array}{l}\text { Conexión Total programme with the } \\
\text { "Red Educativa Nacional" project }\end{array}$ & & \\
\hline & $\begin{array}{l}\text { Programme for use of new technologies } \\
\text { for skills development }\end{array}$ & & \\
\hline \multirow[t]{2}{*}{ Peru } & Huascarán project & Ministry of Education (MINEDU) & First stage: primary education \\
\hline & One Laptop per Child & $\begin{array}{l}\text { Directorate General of Educational } \\
\text { Technologies (DIGETE) }\end{array}$ & Second stage: all levels and teachers \\
\hline
\end{tabular}

Source: Prepared by the authors, on the basis of the United Nations Children's Fund (UNICEF), Las politicas TIC en los sistemas educativos de América Latina. Caso Brasil. Programa TIC y Educación Básica, Buenos Aires, 2014; Las políticas TIC en los sistemas educativos de América Latina. Caso Colombia. Programa TIC y Educación Básica, Buenos Aires, 2014; Las políticas TIC en los sistemas educativos de América Latina: Caso Argentino, Buenos Aires, 2013; Las políticas TIC en los sistemas educativos de América Latina. Caso Chile. Programa TIC y Educación Básica, Buenos Aires, 2013; Las políticas TIC en los sistemas educativos de América Latina. Caso Perú. Programa TIC y Educación Básica, Buenos Aires, 2013. 
The Conectar Igualdad programme was created in April 2010 by Decree $459 / 10$ for the purpose of reducing digital, educational and social gaps in Argentina. Conceived as a federal policy initiative for digital inclusion, it is run by the National Social Security Administration (anses), the Ministry of Federal Planning, Public Investment and Services and the Chief of the Cabinet of Ministers.

Conectar Igualdad is designed to guarantee ICT access and use through the distribution of laptop computers to all students and teachers at secondary schools, special education schools and government-run teacher training institutions. A general objective of the programme is to guarantee a basic level of technological infrastructure, enabling widespread connectivity, the installation of networks and classroom use of computers by students at a 1:1 ratio. This objective is the responsibility of the Ministry of Federal Planning, Public Investment and Services.

To fulfill these objectives, a plan was put in place to gradually distribute netbooks, and as of November 2014 more than 4.5 million had been delivered (ANSES, 2014). Lastly, it should be noted that the programme calls for students and teachers to use the netbooks both at school and at home.
In order to understand the endogenous capacity for technology innovation in Argentina, as well as in adjacent countries, an analysis is needed of the dynamics of the various social actors involved in the projects: the various levels of government, educational institutions, school administrators and teachers, families, ІСт firms and the general public. Depending on context and era, tensions may exist between these actors and what motivates them (UNICEF, 2013a). The Conectar Igualdad programme, as State policy, serves to guide and set the agenda of the various institutions and public and private actors. At the same time, the programme encompasses the Argentina Conectada National Plan, which coordinates the various public policies on ICTs that are being executed by the executive branch.

One aspect that illustrates the complexity of the Conectar Igualdad programme is that it has multiple objectives though with the unambiguous aim of supporting processes to improve educational quality in Argentina (UNICEF, 2013a). To enable the programme to meet its objectives to guarantee quality education and incorporate ICTS in teaching and learning processes, the netbooks come equipped with myriad educational resources, most designed through the Educ.ar portal, as well as software that runs on both Windows and Linux operating systems.

\section{III}

\section{ICTS and academic achievement}

International research shows that to improve student achievement, it is not enough for schools to provide access to ICTs; they must also provide real opportunities to use the technologies as well as adequate quality of access (Selwyn, 2004). Opportunities to use ICTs mean giving students a real chance to interact with the technology, which depends on multiple factors, including the number of Internet-enabled computers that are available to them. Quality of access has to do with the extent to which the available technology is easy to use and how fast and smoothly it operates. This is measured by indicators such as real Internet connection speeds and the ease of startup operations, data exchange and backups of personal data. Ensuring equity in the availability of ICTs is a basic condition for reducing the gap in access, which is the first digital divide (Claro and others, 2011).

Student use of ICTs not only depends on the available opportunities, but also on the type of activity that the new technologies are supporting in the school environment. Learning models that develop cognitive skills and allow for educationally relevant uses should be created and implemented. This leads to the second digital divide, which has to do not with differences in access but rather with differences in uses of ICTS and the ability to benefit from them (Hargittai, 2002; Robinson, DiMaggio and Hargittai, 2003).

ICTS have been introduced in schools to transform teaching and learning processes and improve strategies for academic achievement (Kozma, 2003 and 2008; Sunkel, 2006; Carneiro, Toscano and Díaz, 2009; Rodríguez, Nussbaum and Dombrovskaia, 2013). Accordingly, a number of studies have looked at the effect of these technologies on school performance (Machin, McNally and Silva, 2006; Aristizabal, Caicedo and Escandón, 2009; Spiezia, 2010; Carrillo, Onofa and Ponce, 2010; Cristia and others, 2012). The literature also includes studies 
that have focused on other determinants of educational outcomes but used ICT-related variables as controls.

Research on the determinants of educational outcomes began in the 1960s with the Coleman report (Coleman and others, 1966). Since then, a multitude of studies have looked at personal, family and school factors that affect academic achievement (see Formichella, 2011, or Formichella and Krüger, 2013, for an in-depth review).

Aristizabal, Caicedo and Escandón (2009) analysed the factors that influence school achievement, as measured by the 2006 and 2009 PISA tests, in Colombia. They proposed a structural equation model that allowed them to examine reciprocal and simultaneous dynamics between variables. According to their findings, both ICTs in the home (use of the Internet and related tools, and other devices such as game consoles) and ICTs at school (computers and educational software) have a positive effect on student performance, with the latter making the larger contribution.

However, Spiezia (2010), who analysed the impact of ICTS on average educational outcomes based on the 2006 PISA for all participating countries, highlighted the role of student use of technologies in the home. The author asserted that there was a significant effect on school performance, and in most countries this effect was greater in the case of home use of computers, as opposed to school use. Spiezia thus called into question policies aimed at incorporating the use of computers as a learning tool in the school environment.

Likewise, Machin, McNally and Silva (2006) focused on the case of England, analysing the causal impact of spending to finance ICTS on the educational outcomes of students in various districts. The authors found evidence to support an effect on outcomes in English and science at the primary level, but did not find a similar effect in the case of mathematics.

Meanwhile, Carrillo, Onofa and Ponce (2010) studied the effect of the incorporation of ICTS into the school environment on educational outcomes. Drawing on data for the city of Guayaquil, in Ecuador, the authors analysed a computer-based programme to support mathematics and language teaching at the primary level. They ran an experimental design and concluded that ICTs had a positive impact on mathematics outcomes but no statistically significant impact on language outcomes.

Cristia and others (2012) studied the impact of the "One Laptop per Child" programme in primary schools in the Peruvian countryside and found no evidence of effects on enrolment, dropout or repeat rates. Neither did they find effects on cognitive outcomes in language or mathematics. However, they did identify a positive effect on students' general skills.

In short, the findings of the research cited above are that ICTs have some type of positive effect on student competencies. However, there are some studies that have come to the opposite conclusion. For example, Angrist and Lavy (2002) found that the use of information technology in teaching and learning processes had no relevant effect on academic achievement. The authors arrived at this conclusion after conducting an in-depth analysis of the case of Israel, where a policy-based programme was implemented to increase the availability of computers in a large number of schools in order to improve scholastic outcomes.

Meanwhile, Goolsbee and Guryan (2006) researched the effects of a subsidy programme for Internet use in schools in the state of California, in the United States (known as the E-Rate Program). Drawing on a large set of variables to measure scholastic outcomes, the authors demonstrated that the programme had succeeded in expanding Internet access in the classroom, but found no evidence that this expansion had any effect on academic achievement.

More recent studies have also failed to establish a definitive link between ICTs and academic achievement. Sprietsma (2012) estimated the effect of the availability and use of computers and the Internet as pedagogical tools on the math and reading scores of eighth-grade students in Brazil and found that ICTs, paradoxically, had a negative effect on academic achievement. Witte and Rogge (2014) analysed the effect of ICTs on the academic performance of students in Holland, drawing on data from the 2011 "Trends in International Mathematics and Science Study" (TIMSs). Applying a score matching methodology, the authors found no statistically significant difference between the outcomes obtained by students who had access to technology and made use of it and those who did not.

However, Sprietsma (2012) noted that these unfavourable results could be explained by looking at the way in which students use the technology, which may represent a distraction more than a tool that facilitates learning. Other authors, too, have raised questions about the use of ICTS and described the prerequisites that should be met to ensure that their incorporation into the school environment has positive effects on student academic performance. For example, Barrera-Osorio and Linden (2009) studied the impact of the "Computers for Education" programme in Colombia and analysed the effect of computer use in the school by running an experimental design, with some schools participating in 
the programme and others that were not (control group). The authors found that the incorporation of computers had no effect on learning outcomes, owing to poor use of the technology. This problem, they determined, was related to the fact that even though the programme provided technical assistance and training to teachers, they failed to apply the new techniques in the classroom.

Similarly, the main conclusion of Severín and others (2011), in their analysis of the impact of the "One Laptop per Child" programme in Peru, was that technology is a necessary but insufficient condition for improving educational outcomes. They point to the critical importance of strengthening technological tools with complementary instruments, as well as strengthening the way in which technology is used.

Lastly, the studies conducted by Córdoba Gómez and Herrera Mejía (2013) and by Muñoz and Ortega (2014) are worthy of mention. The former explored the link between ICTs and student performance in mathematics and represents a valuable contribution to the discussion on the effect of use of technologies on educational outcomes. The study looked at student data from two schools in Colombia, in the municipios of Medellín and Duitama. The authors concluded that the incorporation of these technologies in the classroom leads to improvements in academic performance only if teachers receive support from specialists to help them change their teaching practices.

Meanwhile, Muñoz and Ortega (2014) analysed the impact of two plans that were implemented in

\section{IV}

\section{Methodology}

There may be an endogeneity problem with the premise of a relationship between participation in Conectar Igualdad and academic achievement. In other words, the schools that participate in the programme may be different from the schools that do not participate in the programme, and that difference may correlate with academic achievement. Ideally, the potential impact of the Conectar Igualdad programme on the academic achievement of middle-school students would be studied by running an experiment in which participation in the programme was isolated from certain characteristics specific to the schools. However, performing this type of experiment is not feasible.
Chile for the purpose of incorporating the use of ICTS into instruction. The authors studied the determinants of academic achievement as measured by national standardized achievement tests, using the PSM methodology. In general, Muñoz and Ortega concluded that the plans did not have a significant effect on test scores, although they did observe an impact on the language scores in some specific groups of students. They concluded that a necessary goal is to optimize the incorporation of ICTs in the classroom, while taking into account other variables that also affect academic achievement.

In Argentina, there do not appear to be any studies on determinants of academic achievement that have focused on ICTS as a variable. There are, however, studies that have used the variable as a control and found it to have a statistically significant effect. For example, Santos (2007) found that the variable "computers per student" had a positive effect on academic achievement. Decándido (2011) determined that students performed better if they used the Internet to do their work. Formichella and Krüger (2013), Krüger (2013) and Formichella and Ibáñez (2014) identified a positive correlation between the percentage of computers connected to the Internet at a school (Internet access) and academic achievement. Lastly, Formichella and Ibáñez (2014) used an index to represent the ICT-related resources that a student has in the home (including whether he or she has access to educational software, an Internet connection and a computer) and found a positive relationship between that index and academic achievement.
Therefore, a quasi-experimental design suffices when there is no way to control how an individual is assigned to participate in a group (the group of beneficiaries of the Conectar Igualdad programme, in this case) or any of the other factors under analysis.

Because computers are being delivered on a gradual basis under the programme, in 2012 some schools had received them and some had not. With this in mind, the objective of this paper is to determine what would have happened, in terms of academic achievement, to students in schools benefitted by the programme if the schools had not participated. To do this, improvements in the academic performance of students at schools 
participating in the Conectar Igualdad programme must be measured, with performance prior to the intervention as the baseline, and where an improvement in academic performance is the difference between the outcomes obtained by students covered by Conectar Igualdad and the outcomes obtained by students not covered by the programme. A well-known methodology for conducting this type of analysis that is used extensively in impact evaluations is the propensity score matching (PSM) technique of Rosembaum and Rubin (1983), in which a match is artificially constructed for each one of the individuals studied who have identical characteristics but one difference: participation or non-participation in the Conectar Igualdad programme.

PSM can be summarized as follows: (i) the probability that a student will receive treatment (participate in the Conectar Igualdad programme) is estimated and expressed as the student's score; (ii) the sample is divided into two groups - the treatment group (those who receive treatment) and the control group (those who do not receive treatment) — and the two sample groups are arranged in descending order, and (iii) for each individual in the treatment group, an individual with a similar score (probability or propensity) in the control group is identified and pairs are formed (note that one individual in the control group can be matched with more than one individual in the treatment group).

The next step is to calculate the difference in the levels of academic achievement in each pair and the average difference for the sample as a whole. This result is known as the average treatment effect (ATE). Based on the standard error of difference between each pair, a t-test can be run to contrast the null hypothesis of null ATE. If the hypothesis is rejected, it proves that the ATE is statistically different from zero; otherwise, it is not.

In analytical terms, the average effect of a binary treatment on a continuous scale outcome is estimated. For student $i, \mathrm{i}=1, \ldots, \mathrm{N}$, with all units interchangeable, $\left(Y_{i}(0), Y_{i}(1)\right)$ is defined as the two potential outcomes, such that $Y_{i}(0)$ is the academic achievement of student $i$ when the student does not participate in the Conectar Igualdad programme and $Y_{i}(1)$ is the academic achievement of student $i$ when the student is exposed to treatment.
Academic achievement can be measured based on the results obtained by students on any standardized learning test.

If academic achievement when the student participates in the Conectar Igualdad programme, $Y_{i}(1)$, and when the student does not participate, $Y_{i}(0)$, could be observed, the effect of participation in the programme (treatment) on student $i$ would be the difference between $Y_{i}(1)$ and $Y_{i}(0)$. The problem arises because only one of these outcomes can be observed.

$$
Y_{i}=Y_{i}\left(W_{i}\right)=\left\{\begin{array}{l}
Y_{i}(0) \text { if } D_{i}=0 \\
\hline Y_{i}(1) \text { if } D_{i}=1
\end{array}\right.
$$

where $D_{i}$ indicates participation or non-participation in the Conectar Igualdad programme. According to the models used by Roy (1957), Quandt (1972) and Rubin (1978), it is assumed that the academic achievement of students would be:

$$
\begin{aligned}
& Y_{1}=\mu_{1}(X)+U_{1} \\
& Y_{0}=\mu_{0}(X)+U_{0}
\end{aligned}
$$

The gain in terms of academic achievement is expressed as $\Delta=Y_{1}-Y_{0}$. If $Y_{1}$ and $Y_{0}$ were observable for each student, evaluating the impact of treatment (participation in the Conectar Igualdad programme) would not be a problem. However, it is not often the case that both variables can be observed at the same time for the same student. To resolve this problem, policies are evaluated using different versions of averages of variations on the target population. One method is the average treatment effect (ATE) on the cases receiving treatment.

A comparison of the averages of academic results by participation or non-participation in the programme reveals something about potential achievement, while not necessarily explaining the phenomenon. A comparison of average academic performance, considering the condition "programme participation," is formally related to the average causal effect expressed by the following equation:

$$
\underbrace{E\left(Y_{i} \mid D_{i}=1\right)-E\left(Y_{i} \mid D_{i}=0\right)}_{\begin{array}{c}
\text { Difference observed in } \\
\text { average academic } \\
\text { achievement }
\end{array}}=\underbrace{\left[E\left(Y_{1 i} \mid D_{i}=1\right)-E\left(Y_{0 i} \mid D_{i}=1\right)\right]}_{\begin{array}{c}
\text { ATT: average treatment effect } \\
\text { of programme participation } \\
\text { on the treated }
\end{array}}+\underbrace{\left[E\left(Y_{0 i} \mid D_{i}=1\right)-E\left(Y_{0 i} \mid D_{i}=0\right)\right]}
$$


In terms of the treatment effect on the treated, there is a problem in that the data do not usually include observations of academic achievement $Y_{0}$ for students participating in the programme $(\mathrm{D}=1)$. The problem of selection bias (Heckman, 1990) is a result of this lack of information. The matching method resolves the selection bias problem by replacing randomization with the conditionalizationof regressors. Selection bias is eliminated only if treatment has been purely random among students with the same propensity score.

The PSM process serves to reduce selection bias, making it possible to estimate treatment effects with observable data. To this end, an estimate is made from a logit or probit model, where the function of maximum likelihood is more important than the significance of the estimators (Heckman, Lalonde y Smith, 1999).

There are various methods for estimating the impact on the treatment effect based on PSM, which differ basically depending on the way in which the distance between the treatment and control is defined. These methods include the following:

(i) Nearest neighbor matching, an estimator that matches students in the treatment and control groups, taking a treated unit for every control unit based on the closest propensity score. A control-group student $j$ is selected as a match for student $i$, so that formally the control group for student $i, \mathrm{C}^{\mathrm{o}}$ (pi) with PSM pi, is a single student $j$ that meets this condition: $\mathrm{C}(\mathrm{i})=\min j\left\|\mathrm{P}_{i}-\mathrm{P}_{j}\right\|$. The control student $j$ selected from the control group is the student that minimizes the difference between his/her propensity score and the propensity score of the student in the treatment group. For this estimator, one student from the control group (those not participating in the Conectar Igualdad programme) is used for comparisons with each student in the treatment group. In this case, the average treatment effect on the treated (ATT) is called ATTND ( $\mathrm{N}$ for nearest neighbor).

(ii) Kernel estimator, a method in which treated students (i.e. students who received netbooks) are matched with a weighted average of all students in the control group, using weights that are inversely proportional to the distance between the propensity score of the treated students and the propensity score of the control students. In this case, the ATT is known as ATTK (K for Kernel).

(iii) Stratification, a method for matching between cases and controls based on a variable that contains the block number (strata) to which the common support region pertains. The common support region involves giving consideration in the estimate of the average effect of treatment on the treated (ATT) to the students that fall within the range bounded by minimum and maximum propensity scores of the students in the treatment group. This ensures that the defined region has values with positive density for students in both the treatment and control groups (Smith and Todd, 2005). In this case, the ATT is known as ATTS (s for stratification matching).

\section{Data}

This study draws on data from the PISA tests, which have been administered by the OECD every three years since 2000 in order to assess the competencies of 15-yearold students in various countries. The PISA tests cover mathematics, science and language, with one of these subjects chosen as an area of focus on a rotating basis for each round of testing. As part of the PISA test, information is also gathered on the social context of the students and schools that they attend (OECD, 2009).

Argentina participated in the 2000, 2006, 2009 and 2012 rounds of PISA testing. This paper draws on the 2012 data set, which is the most recent and contains information subsequent to the implementation of the Conectar Igualdad programme, the focal point of this study. ${ }^{2}$

Scoring on PISA tests is designed for a mean of 500 and a standard deviation of 100 . The results of the assessments are presented using plausible values, which are a representation of a student's competencies. Given that the objective of the PISA tests is to evaluate the skills of an entire population group, as opposed to the individuals within it, each student answers a certain number of items, from which an extrapolation is made as to how he or she would have answered the rest of the items. The PISA team prepares five plausible values for each area based on the information obtained (OECD, 2009).

As a result, the correct method for consistently estimating any statistical value and thus any parameter of a model consists in calculating each one of the five values separately and then obtaining the average (OECD, 2009). This is the procedure that has been followed for this study.

\footnotetext{
2 It should be noted that there is no way to ascertain the academic achievement of individual students over time, because the PISA tests are only administered to 15-year-old students, which means that a new set of students is assessed during each round, yielding transversal information only. Moreover, use of the matching methodology is justified by the fact that there is no way to track the academic achievement of an individual student in both scenarios (with the Conectar Igualdad programme and without it) over the same period of time. Matching provides a way to artifically compare achievement in both scenarios.
} 


\section{Variables}

The main variable of interest for this study is a binary variable known as Conectar that assigns a value of 1 if the student attends a school covered by the Conectar Igualdad programme and a value of 0 otherwise. In other words, it assigns treatment to students at schools that participated in the programme in 2012. For this purpose, the school identifier was SCHOOLID and the student identifier was STIDSTD.

Inasmuch as Argentina has not participated in the PISA special module on ICTs, the database does not provide any information on which schools are participating in the Conectar Igualdad programme and which are not. Therefore, the Conectar variable is constructed by inference in this study.

As mentioned, the programme has been implemented only in public schools, so a value of 0 is assigned for the variable in all cases in which a student attends a private school. In the case of public schools, other variables are used to determine whether the school was or was not covered by the programme.

The following two questions on the questionnaire completed by school administrators were considered:

(i) Number of students in the 15-year-old age group (SC11Q01).

(ii) Number of computers available for educational purposes for 15-year-old students (SC11Q02).

Based on these variables, the total number of students was divided by the number of available computers to calculate the number of computers per student. Public schools in which at least $95 \%$ of 15 -year-old students had a computer were assumed to participate in the Conectar Igualdad programme. ${ }^{3}$

The foregoing assumption makes more sense upon observing the same information for 2009, prior to implementation of the programme. At that time, the aforementioned condition was met only in the case of $1.5 \%$ of the students attending public schools. Meanwhile, in 2012, two years after programme startup, the percentage had risen to $19.9 \%$, an improvement of 18 percentage points, or a $12 \%$ increase. $^{4}$

\footnotetext{
3 Although the programme called for every student to have access to a computer to study at school (which would mean considering only those schools with a computer-student ratio equal to $100 \%$ or greater), a decision was made to relax this condition $(95 \%)$ on the recommendation of key informants who pointed out some operational issues that produced a situation in which a small fraction of students attending schools covered by the programme would not have a computer.

4 The assumption also makes more sense considering the situation in private schools, where the condition was met in the case of $9 \%$ of
}

As described in section II of this paper, the Conectar Igualdad programme calls for the use of netbooks not only at school but also in the home, such that students can take them home to do their homework. The PISA survey contains information on the availability of computers in the home. Participants in the Conectar Igualdad programme include students attending schools that issue computers to at least $95 \%$ of the student body and students with a computer in the home (provided that programme conditions are met).

The variables considered for calculating the likelihood of programme participation are as follows:

- Repeater: a dichotomous variable that takes a value of 1 if the student has repeated a grade in primary or secondary school.

- Secondary studies: a dichotomous variable that takes a value of 1 if the highest educational level achieved by the parents is a secondary-level diploma or preparatory cycles (middle or upper grade).

- Tertiary studies: a dichotomous variable that takes a value of 1 if the highest educational level achieved by the parents is a university degree.

- Auto2: a dichotomous variable that takes a value of 1 if the student's family has two or more automobiles.

- Unemployed: a dichotomous variable that takes a value of 1 if the student's mother or father does not have a job.

- Urban: a dichotomous variable that takes a value of 1 if the school is located in an area with a population of 15,000 people or more, and 0 otherwise.

- ESCS average: a continuous variable that reflects the social composition of the student. It is calculated as the average of the economic, social and cultural status index $(\mathrm{ESCS})^{5}$ of the school. The PISA team at the OECD prepares an ESCS indicator for each student that summarizes the information on parental occupational status, parental educational level and household cultural and material possessions (OECD, 2009).

The ESCS is calculated using other indexes also presented by the PISA team: the index of highest occupational status of parents (HISEI), the number of years of schooling of parents (PARED) and the index of home

students in 2009 and $22 \%$ in 2012, an improvement of 13 percentage points, or just $1.4 \%$. In short, the overall increase in the percentage of students for whom the condition was met (from $4.5 \%$ to $15.9 \%$ ) can be attributed, above all, to the change that occurred in the public schools with the Conectar Igualdad programme.

5 This index and the others described in this section have been constructed by the PISA team such that a positive value signifies that the household level is above the average of the OECD countries and a negative value signifies that the household level is below the average. 
possessions (HOMEPOS). The information summarized in each index is described below:

HISEI: this index represents the occupational status of the students' parents, and the value corresponds to the higher value between the mother and father.

PARED: this index represents the educational level of the parents, measured as the number of years of schooling, and the value corresponds to the highest level achieved by the mother or father.

HOMEPOS: this index summarizes information on the number of books in the home and the wealth (WEALTH), home educational resources (HEDRES) and cultural possessions (CULTPOS) indexes.

WEALTH represents the quantity of material possessions, HEDRES the quantity of education resources; and CULTPOs the quantity of cultural possessions in the student's home.

- Internet_home: a dichotomous variable that takes a value of 1 if the student has Internet service at home.

- COMPWEB: a continuous variable that is defined as the proportion of Internet-enabled computers for educational purposes at the school.

\section{Descriptive analysis}

The 2012 PISA sample for Argentina consists of 5,908 observations, of which $15.9 \%$ correspond to students attending schools covered by the Conectar Igualdad programme. However, the decision was made to exclude from the analysis those students who have a computer at home but do not participate in the programme. This decision was made in response to the fact that in order to accurately assess the effect of treatment on the treated, academic achievement in the control group must be independent of the assignment of treatment. The availability of computers in the home could affect the academic achievement among the control group.

Working with subsamples has been observed in other studies (Dehejia and Wahba, 2002; Johar, 2009). The latter evaluates the effectiveness of a national health programme in Indonesia, for which it selected only adults (older than 15 years) from the sample inasmuch as children's health would be very difficult to interpret. As children become adults, the frequency of regular checkups naturally declines. Johar (2009) also runs PSM for subgroups (heads of household, children and others) so that the groups have more characteristics in common.

Based on the PISA data, 1,922 students were selected, 938 of whom participated in the Conectar Igualdad programme (see figure 2).
As illustrated in table 2, the average achievement scores are greater in the programme beneficiary group for the three competencies evaluated by PISA.

However, the problem with running a simple comparison of averages of student academic performance with and without the Conectar Igualdad programme is that the programme assignment process has not been random. As a result, differences in academic performance may be the result of characteristics specific to the students (individual, scholastic, sociodemographic and other characteristics) that induce certain individuals to participate in the Conectar Igualdad programme while others do not. Table 3 shows the main characteristics of both groups of students, i.e. with Conectar Igualdad and without Conectar Igualdad, prior to matching. The data are from the PISA 2012 test.

The observation can be made that among the students in schools participating in the Conectar Igualdad programme, there are fewer students who repeat grades, a larger proportion of parents with tertiary education, a smaller proportion of unemployed parents, a larger proportion of homes with Internet access, a larger proportion of Internet-enabled computers at the school and a larger proportion of schools with a high socioeconomic level. These average differences between the two groups are statistically significant according to the analysis of variance (ANOVA). The average difference between the two groups with respect to the proportion of parents with secondary schooling is the only difference that is not statistically significant.

FIGURE 2

\section{Students participating in the Conectar Igualdad programme}

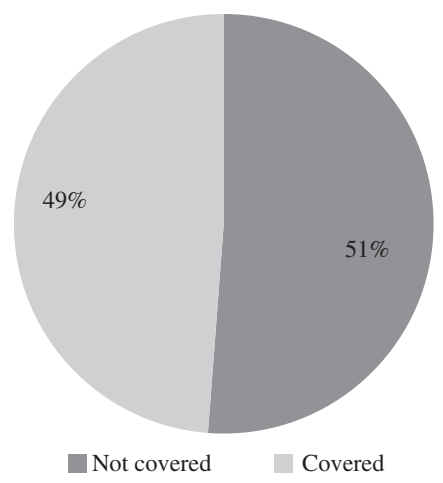

Source: Prepared by the authors, on the basis of data from PISA 2012 test. 
TABLE 2

Differences in averages of academic achievement

\begin{tabular}{lccc}
\hline \multicolumn{1}{c}{ Competencies } & With Conectar Igualdad & Without Conectar Igualdad & Difference in averages \\
\hline Mathematics & 397.033576 & 351.374268 & $45.6593081^{*}$ \\
Reading & 402.013162 & 347.956902 & $54.056261^{*}$ \\
Science & 409.325116 & 361.588903 & $47.736213^{*}$ \\
\hline
\end{tabular}

Source: Prepared by the authors.

Note: * statistically significant at $1 \%$.

TABLE 3

\section{Descriptive statistics}

\begin{tabular}{|c|c|c|c|c|c|c|c|}
\hline Variable & $\begin{array}{c}\text { Group } \\
\text { (with or without } \\
\text { Conectar) }\end{array}$ & Observations & Average & $\begin{array}{l}\text { Standard } \\
\text { deviation }\end{array}$ & Minimum & Maximum & ANOVA \\
\hline Repeater & $\begin{array}{l}\text { With } \\
\text { Without }\end{array}$ & $\begin{array}{l}750 \\
654 \\
\end{array}$ & $\begin{array}{l}0.21466 \\
0.39908 \\
\end{array}$ & $\begin{array}{l}0.41085 \\
0.49005 \\
\end{array}$ & $\begin{array}{l}0 \\
0\end{array}$ & $\begin{array}{l}1 \\
1 \\
\end{array}$ & $* * *$ \\
\hline Secondary studies & $\begin{array}{l}\text { With } \\
\text { Without }\end{array}$ & $\begin{array}{l}906 \\
914\end{array}$ & $\begin{array}{l}0.20529 \\
0.22100 \\
\end{array}$ & $\begin{array}{l}0.40412 \\
0.41512 \\
\end{array}$ & $\begin{array}{l}0 \\
0\end{array}$ & $\begin{array}{l}1 \\
1\end{array}$ & Ns \\
\hline Tertiary studies & $\begin{array}{l}\text { With } \\
\text { Without }\end{array}$ & $\begin{array}{l}906 \\
914 \\
\end{array}$ & $\begin{array}{l}0.53200 \\
0.30087 \\
\end{array}$ & $\begin{array}{l}0.49925 \\
0.45889 \\
\end{array}$ & $\begin{array}{l}0 \\
0 \\
\end{array}$ & $\begin{array}{l}1 \\
1\end{array}$ & $* * *$ \\
\hline Auto2 & $\begin{array}{l}\text { With } \\
\text { Without }\end{array}$ & $\begin{array}{l}891 \\
877\end{array}$ & $\begin{array}{l}0.18967 \\
0.08208 \\
\end{array}$ & $\begin{array}{l}0.39224 \\
0.27461 \\
\end{array}$ & $\begin{array}{l}0 \\
0 \\
\end{array}$ & $\begin{array}{l}1 \\
1\end{array}$ & $* * *$ \\
\hline Unemployed & $\begin{array}{l}\text { With } \\
\text { Without }\end{array}$ & $\begin{array}{l}800 \\
726\end{array}$ & $\begin{array}{l}0.14875 \\
0.27415 \\
\end{array}$ & $\begin{array}{l}0.35605 \\
0.44637 \\
\end{array}$ & $\begin{array}{l}0 \\
0\end{array}$ & $\begin{array}{l}1 \\
1\end{array}$ & $* * *$ \\
\hline Urban & $\begin{array}{l}\text { With } \\
\text { Without }\end{array}$ & $\begin{array}{l}938 \\
957 \\
\end{array}$ & $\begin{array}{l}0.59483 \\
0.61651 \\
\end{array}$ & $\begin{array}{l}0.49117 \\
0.48649 \\
\end{array}$ & $\begin{array}{l}0 \\
0 \\
\end{array}$ & $\begin{array}{l}1 \\
1 \\
\end{array}$ & $* * *$ \\
\hline $\begin{array}{l}\text { Average } \\
\text { socioeconomic level }\end{array}$ & $\begin{array}{l}\text { With } \\
\text { Without }\end{array}$ & $\begin{array}{l}938 \\
984\end{array}$ & $\begin{array}{l}-0.55933 \\
-1.09734 \\
\end{array}$ & $\begin{array}{l}0.71468 \\
0.63107 \\
\end{array}$ & $\begin{array}{l}-1.8635 \\
-2.695\end{array}$ & $\begin{array}{l}1.075 \\
1.075\end{array}$ & $* * *$ \\
\hline Internet_home & $\begin{array}{l}\text { With } \\
\text { Without }\end{array}$ & $\begin{array}{l}884 \\
845\end{array}$ & $\begin{array}{l}0.85857 \\
0.19526 \\
\end{array}$ & $\begin{array}{l}0.34864 \\
0.39664 \\
\end{array}$ & $\begin{array}{l}0 \\
0\end{array}$ & $\begin{array}{l}1 \\
1\end{array}$ & $* * *$ \\
\hline COMPWEB & $\begin{array}{l}\text { With } \\
\text { Without }\end{array}$ & $\begin{array}{l}851 \\
885\end{array}$ & $\begin{array}{l}0.90307 \\
0.93442\end{array}$ & $\begin{array}{l}0.25583 \\
0.21881\end{array}$ & $\begin{array}{l}0 \\
0\end{array}$ & $\begin{array}{l}1 \\
1\end{array}$ & $* * *$ \\
\hline
\end{tabular}

Source: Prepared by the authors.

Note: Auto2: Dichotomous variable that takes a value of 1 if the student's family has two or more automobiles; ANOvA: Analysis of variance; COMPWEB: A continuous variable that is defined as the proportion of Internet-enabled computers for educational purposes at the school; Ns $=$ Not significant.

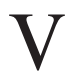

\section{Results}

First, the PSM is estimated using a probit model that includes the explanatory variables for participation in the Conectar Igualdad programme. For the estimate of likelihood, only those variables that simultaneously affect the decision to participate and the outcome variable should be included (Bernal and Peña, 2011).

The dependent variable is:

Conectar Igualdad: this is a binary variable that takes the value of 1 if the student attends a school that is already covered by the programme, and 0 otherwise. It is assumed that if the school is covered by the programme, all students have a computer that has been issued to them under the programme.

The probit model used by the programme, STATA 12 , comes from a latent or non-observable variable in the model, $\mathrm{y}^{*}$, which indicates the likelihood that a student will participate in the programme. This variable is explained by a series of observable independent variables in the following structural equation: 


$$
y^{*}=\beta 0+x \beta+e \cdot y=1\left[y^{*}>0\right]
$$

The relationship between the binary observable variable (if the school has been benefitted by the programme) and the latent variable $y^{*}$ (likelihood to participate in the programme) is represented by the following equation:

$$
\begin{aligned}
& y=1 \text { if } y^{*}>0 \\
& y=0 \text { if } y^{*} \leq 0
\end{aligned}
$$

Studies on implementation of the Conectar Igualdad programme, as well as assessments of academic achievement, provide information on the factors that influence programme participation.

\section{Treatment effect: participation in the Conectar Igualdad programme}

The objective is to identify the average effect of programme participation on the academic achievement of 15-yearold students in Argentina.
The PSM is valid if the observed variables are understood to determine participation (in the Conectar programme), i.e., if there is no bias due to non-observable variables or if the non-observable or unavailable variables are not a fundamental determinant of either participation in the programme or of the potential outcome variables, such as academic achievement (Bernal and Peña, 2011).

Estimating the propensity score using STATA 12 produces the results presented in table 4 . The model is a good fit. Overall, the model is significant in accordance with the likelihood ratio statistic (prob $>$ chi $2=0.0000$ ) and Pseudo $\mathrm{R}^{2}$.

Subsequently, the matching technique is used to define a region of common support. The selected region has been [0.05431384, 0.9742593]. Figure 3 shows the Kernel density of the estimated propensity score, in which the region of common support can be seen.

Figure 3 shows two density functions, one for the treatment group (grey line) and another for the control group (black line). This function suggests that the average likelihood of programme participation for the treatment group is higher than the average for the control group.

TABLE 4

Determinants of participation in the Conectar Igualdad programme

\begin{tabular}{lccc}
\hline Variables & Coefficient & Standard error & Level of significance \\
\hline Repeater & -0.2720347 & 0.1163132 & $* *$ \\
Secondary studies & -0.1118963 & 0.139605 & Ns \\
Tertiary studies & 0.1032862 & 0.1257226 & Ns \\
Auto2 & 0.1476435 & 0.1469592 & Ns \\
Unemployed & -0.2393344 & 0.1326774 & $*$ \\
Urban & -0.1304947 & 0.1059158 & Ns \\
Average socioeconomic level & 0.1754671 & 0.0850824 & $* *$ \\
Internet_home & 1.774768 & 0.1109653 & $* *$ \\
COMPWEB & -0.4561941 & 0.2155834 & Ns \\
Constant & -0.0674548 & 0.2647191 & \\
No. of observations & 951 & & \\
LR chi2 $(9)$ & 495.93 & & \\
Prob>chi2 & 0.0000 & & \\
Pseudo R & & & \\
\hline
\end{tabular}

Source: Prepared by the authors.

Note: $* * *$, ** significant to $1 \%$ and $5 \%$ respectively; Ns $=$ Not significant.

COMPWEB: A continuous variable that is defined as the proportion of Internet-enabled computers for educational purposes at the school; Auto2: Dichotomous variable that takes a value of 1 if the student's family has two or more automobiles. 
FIGURE 3

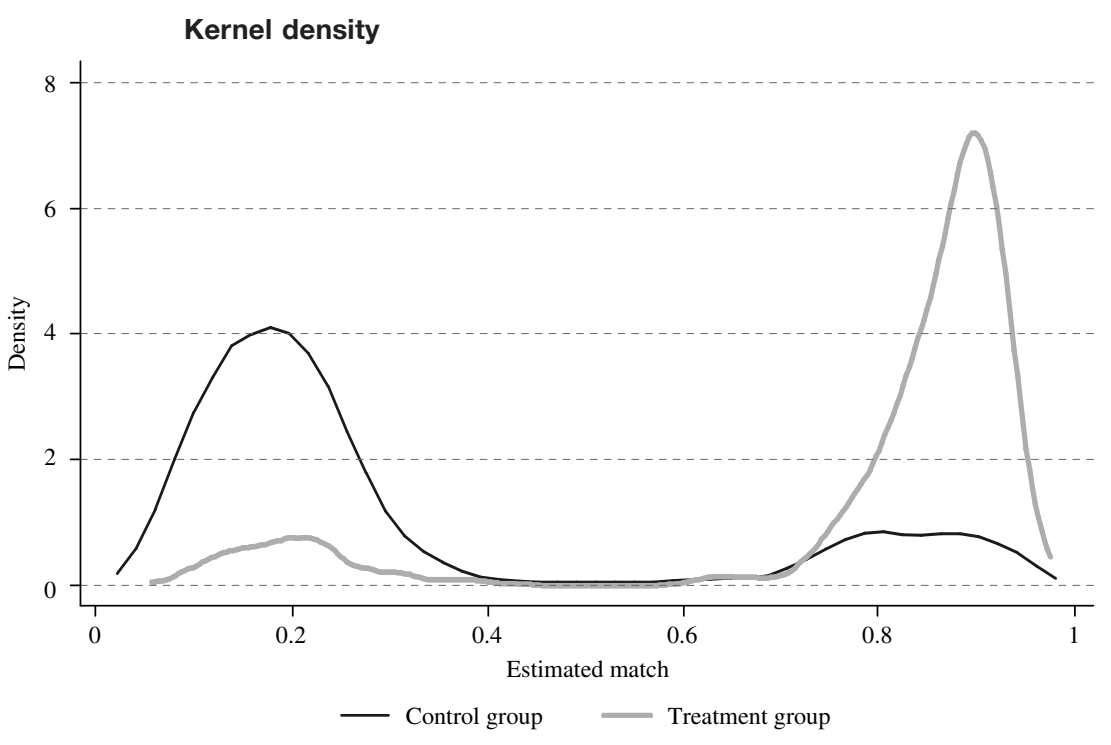

Type of Kernel function: Epanechnikov, bandwidth: 0.0316.

Source: Prepared by the authors.

Of the 1,922 fifteen-year-old students in Argentina, 949 are confirmed to correspond to the region of common support. Of the students in this region, 557 are in the treatment group and 392 are in the control group (see table 5).

TABLE 5

\begin{tabular}{lccc}
\multicolumn{4}{c}{ Distribution of cases } \\
\hline \multicolumn{1}{c}{ Students } & $\begin{array}{c}\text { No. of } \\
\text { observations }\end{array}$ & Percentage & $\begin{array}{c}\text { Cumulative } \\
\text { percentage }\end{array}$ \\
\hline Control & 392 & 41.31 & 41.31 \\
Treatment & 557 & 58.69 & 100 \\
Total & 949 & 100 & \\
\hline
\end{tabular}

Source: Prepared by the authors.

As observed, the control group is large (392 students), which is a necessary condition for the fit of the model. The results indicate that the socioeconomic level of the school, as well as the availability of Internet in the home, have a significant positive effect on the likelihood of participation in the programme. Meanwhile, students who repeat grades and have unemployed parents are significantly less likely to participate in the programme. The COMPWEB variable has a significant negative effect, as schools with a large proportion of Internet-enabled computers are less likely to participate in the programme.

Therefore, in principle, the schools that are most in need of the programme - that is, those without Internet- enabled computers, with a lower average socioeconomic level, with a larger proportion of students who repeat grades and are more likely to have unemployed parents and no Internet access at home- are less likely to participate in the programme. ${ }^{6}$

Subsequently, the score estimated with the PSM method was used. The differences in the levels of academic achievement predicted by the model using the various matching techniques to estimate the average effect of treatment on the treated (ATT) can be observed in table 6: the difference in the average academic achievement between students attending schools benefitted by the Conectar Igualdad programme and students without access to the programme is statistically significant under the stratification and Kernel methods. However, the nearest neighbor technique does not yield any statistically significant evidence.

\footnotetext{
${ }^{6}$ This assertion is based on an examination of the variables that have been used for the student matching exercise and that were found to be statistically significant. The reason why schools with unfavourable socioeconomic conditions do not participate in the programme or delay in doing so is beyond the scope of this study. However, based on communication with key informants, one possible hypothesis follows. To participate in the programme, school administrators must file a formal request with the National Social Security Administration (ANSES), but administrators at the schools with the most challenging social problems have less time and energy to devote to such endeavors. This does not exclude their schools from the programme, but it does mean that they take longer to join than do schools with more resources that serve students in better socioeconomic conditions. This hypothesis will be tested in future studies.
} 
TABLE 6

Estimate of ATT in tests

\begin{tabular}{|c|c|c|c|c|c|}
\hline Test & PSM & Treatment group & Control group & ATT & Value of student $t$-statistic \\
\hline \multirow[t]{3}{*}{ Mathematics } & ATTS & 557 & 392 & 18.9468 & 2.1874 \\
\hline & ATTK & 557 & 392 & 22.2852 & 2.9056 \\
\hline & ATTND & 557 & 135 & 11.1794 & 1.1474 \\
\hline \multirow[t]{3}{*}{ Reading } & ATTS & 557 & 392 & 25.1496 & 2.6202 \\
\hline & ATTK & 557 & 392 & 28.8056 & 3.0984 \\
\hline & ATTND & 557 & 135 & 19.8906 & 1.6596 \\
\hline \multirow[t]{3}{*}{ Science } & ATTS & 557 & 392 & 18.2304 & 1.7668 \\
\hline & ATTK & 557 & 392 & 20.7718 & 2.4338 \\
\hline & ATTND & 557 & 135 & 12.2406 & 1.245 \\
\hline
\end{tabular}

Source: Prepared by the authors, on the basis of data from PISA 2012 test.

Note: ATT: Average treatment on the treated; ATTK: Average treatment on the treated, Kernel method; ATTND: Average treatment on the treated, nearest neighbor method; ATTS: Average treatment on the treated, stratification method; PSM: Propensity score matching.

Therefore, the hypothesis that there are no differences in academic achievement between students in the treatment group (i.e. students participating in the Conectar Igualdad programme) and students in the control group is rejected. Although the difference in the tests is statistically significant, its average size is small. This minimal impact on academic achievement is evidence that the programme, though still in the early stages, is not being used to its full potential. As specified in the programme, making appropriate use of the netbooks requires more than just putting them into the hands of students. Teachers must incorporate them into the way that they teach and the way that students learn. In addition, distribution of the netbooks must by complemented by a minimum level of Internet access and installation of these computers at the schools. In other words, in addition to distributing the computers, the programme calls for support to be provided by trained technical personnel, as well as training for teachers to put the technology to educational use in the classroom.

Evidence that the programme has not yet moved beyond the stage of mere access to computers at school is the fact that the impact of the programme on academic achievement is very similar to the impact seen when computers are available in the home. The PSM estimate of the effect of computers in the home on student performance yields average treatment effect (ATE) results that are very similar to those obtained in the case of participation in the Conectar Igualdad programme. Although the target populations are different -in the latter case, all 15-year-old students in Argentina are studied based on PISA test data - the differences between the two groups are minimal (see Table 7). ${ }^{7}$

Lastly, according to Nannincini (2007), the estimated model is demonstrably robust, inasmuch as estimates of the average effect of treatment on the treated (АTT) have been specified under different possible scenarios that deviate from the assumption of conditional independence. In other words, the proposal is to simulate the capacity of a non-observable variable (not included in the probability estimate) to generate bias. To this end, alternative ATT estimates were calculated, incorporating additional binary variables, and none yielded results that were different than the ATT obtained with the model. Neither were differences found between the original impact and the impacts on academic achievement with the incorporation of additional variables.

\footnotetext{
7 The study presented in this paper focuses on a subsample consisting of 1,922 observations, whereas the proposed study that would research the impact of the computer variable is based on the total 2012 PISA sample for the Argentina. The fact that both samples include students who benefit from Conectar Igualdad does not condition the results obtained the proposed exercise because the percentage of students in that situation is low (18\%).
} 
ATT comparison between access to a computer at home and participation in the Conectar Igualdad programme

\begin{tabular}{|c|c|c|c|}
\hline PSM & ATT computer & ATT Conectar & Difference \\
\hline & \multicolumn{3}{|c|}{ Mathematics } \\
\hline ATTS & 19.7312 & 18.9468 & 0.7844 \\
\hline ATTK & 36.8288 & 22.2852 & 14.5436 \\
\hline \multirow[t]{2}{*}{ ATTND } & 18.1634 & 11.1794 & 6.984 \\
\hline & \multicolumn{3}{|c|}{ Reading } \\
\hline ATTS & 24.9462 & 25.1496 & -0.2034 \\
\hline ATTK & 49.9536 & 28.8056 & 21.148 \\
\hline \multirow[t]{2}{*}{ ATTND } & 27.2636 & 19.8906 & 7.373 \\
\hline & \multicolumn{3}{|c|}{ Science } \\
\hline ATTS & 16.9556 & 18.2304 & -1.2748 \\
\hline ATTK & 38.7098 & 20.7718 & 17.938 \\
\hline ATTND & 18.9388 & 12.2406 & 6.6982 \\
\hline
\end{tabular}

Source: Prepared by the authors.

Note: PSM: Propensity score matching; ATT: Average treatment on the treated; ATTK: Average treatment on the treated, Kernel method; ATTND: Average treatment on the treated, nearest neighbor method; ATTS: Average treatment on the treated, stratification method; PSM: Propensity score matching.

\section{Final considerations}

This paper has explored the role of ICTs in education and, in particular, their effect as a determinant of academic achievement. Specifically, it has analysed the impact of the Conectar Igualdad programme in Argentina from a quantitative perspective, in order to complement the qualitative studies that have already been carried out and contribute to a better understanding of the use and effect of ICTs on the learning process.

In summary, this paper has made two contributions: it has expanded the base of knowledge on the role of ICTS in education, and it has evaluated the impact of the Conectar Igualdad programme in Argentina.

With respect to the results, using the propensity score matching (PSM) technique and drawing on data from the corresponding PISA tests to 2012 for Argentina, a statistically significant difference in average academic achievement was found between the group of students who were beneficiaries of the programme and those who were not. However, this difference does not necessarily translate into a major qualitative difference in academic achievement inasmuch as the absolute value of the average differences is low. Accordingly, future studies should explore whether participation in the Conectar Igualdad programme leads to a decrease in the rate of academic failure.
The lack of explicit data on the participation of schools in the Conectar Igualdad programme is not considered to be an important limiting factor in the study because the variables used to corroborate programme participation have been found to be logical and consistent, a fact borne out by comparisons with data from 2009 prior to implementation of the programme.

The effect that ICTs have on academic achievement has also been analysed, using the availability of computers in students' homes as a treatment variable. The observation is that participation in the programme, the scope of which goes beyond simply making computers available, yields similar results in terms of academic achievement. This suggests the need to tap the full potential of the programme, the results of which have not yet gone beyond access to computers.

The majority of studies analysing the impact of ICTS on education are based on weak indicators. A typical indicator of ICTS in schools has been the number of available computers.

Lastly, it should be noted that ICTs in education is a new area of inquiry, so further analysis and discussion is needed. In addition, research on the impact of public policies for universal access to ICTs requires long-term monitoring to track the effects of implementation of the programme over time. 


\section{Bibliography}

Angrist, J. and V. Lavy (2002), "New evidence on classroom computers and pupil learning", The Economic Journal, vol. 112, No. 482, Royal Economic Society.

ANSES (National Social Security Administration) (2014), "La ANSES ya entregó casi cuatro millones de netbooks a traves de Conectar Igualdad" [online] www.conectarigualdad.gob.ar.

Aristizabal, G., M. Caicedo and D. Escandón (2009), "Las tecnologías de la información y comunicación como determinante en el rendimiento académico escolar, Colombia 2006-2009" [online] http://2012.economicsofeducation.com.

Barrera-Osorio, F. and L. Linden (2009), "The use and misuse of computers in education. Evidence from a randomized experiment in Colombia", Policy Research Working Paper, No. 4836, Washington, D.C., World Bank.

BECTA (2007), "Inclusive Learning: an Essential Guide" [online] http://www.tes.co.uk/teachingresource/Inclusive-learning-anessential-guide-6072357/.

Bernal, R. and X. Peña (2011), Guía práctica para la evaluación de impacto, Santiago, Ediciones UC.

Carneiro, R., J.C. Toscano and T. Díaz (2009), Los desafíos de las TIC para el cambio educativo, Madrid, Organization of Ibero-American States for Education, Science and Culture-Fundación Santillana.

Carrillo, P., M. Onofa and J. Ponce (2010), "Information technology and student achievement: evidence from a randomized experiment in Ecuador", IDB Working Paper, No. 223, Washington, D.C., Inter-American Development Bank (IDB).

Castells, M. (1999), La era de la información. Economía, sociedad y cultura, Madrid, Siglo XXI.

Claro, M. (2011), "El papel de las tecnologías de la información y las comunicaciones en la educación inclusiva", Project Document (LC/W.434), Santiago, Economic Commission for Latin America and the Caribbean (ECLAC).

Claro, M. and others (2011), "Aporte del sistema educativo a la reducción de las brechas digitales. Una mirada desde las mediciones PISA", Project Document (LC/W.456), Santiago, Economic Commission for Latin America and the Caribbean (ECLAC)

Coleman, J. and others (1966), Equality of Educational Opportunity, Washington, D.C., United States Government Publishing Office.

Córdoba Gómez, F. and H. Herrera Mejía (2013), "Impacto del uso de objetos de aprendizaje en el desempeño en matemáticas de estudiantes de grado noveno", Revista Virtual Universidad Católica del Norte, No. 39.

Cristia, J. and others (2012), "Technology and child development: evidence from the one laptop per child program", IDB Working Paper, No. 63438 [online] http://www.iadb.org/en/researchand-data.

Decándido, G. (2011), "Factores que afectan las competencias de los alumnos argentinos en PISA 2009. Un estudio empírico de dos niveles con efectos de interacción", Anales de la Asociación Argentina de Economía Política [online] http://www.aaep.org.ar.

Dehejia, R. and S. Wahba (2002), "Propensity score matching methods for non experimental causal studies", The Review of Economics and Statistics, vol. 84, No. 1, Cambridge, Massachusetts, The MIT Press.

Federal Education Council (2010), "Las políticas de inclusión digital educativa. El Programa Conectar Igualdad" [online] http://www. me.gov.ar/consejo/resoluciones/res10/123-10_01.pdf.

Formichella, M.M. (2011), "Do private schools in Argentina perform better because they are private?", CEPAL Review, No. 105 (LC/G.2508-P), Santiago, Economic Commission for Latin America and the Caribbean (ECLAC).

Formichella, M.M. and M. Ibáñez (2014), "Género e inequidad educativa: un análisis para el nivel medio en Argentina”, Estudios Económicos Regionales y Sectoriales, vol. 14, No. 1.
Formichella, M.M. and N. Krüger (2013), "El fracaso escolar en el nivel medio argentino: ¿es menos frecuente en las escuelas de gestión privada debido a su administración?", Estudios Económicos Regionales y Sectoriales, vol. 13, No. 3.

Goolsbee, A. and J. Guryan (2006), "The impact of internet subsidies in public schools", The Review of Economics and Statistics, vol. 88, No. 2, Cambridge, Massachusetts, The MIT Press.

Hargittai, E. (2002), "Second-level digital divide: difference in peoples online skills", First Monday, vol. 7, No. 4 [online] http://firstmonday.org/htbin/cgiwrap/bin/ojs/index.php/fm/ article/view/942/864.

Heckman, J. (1990), "Varieties of selection bias", American Economic Review, vol. 80, No. 2, Nashville, Tennessee, American Economic Association.

Heckman, J., R. Lalonde and J. Smith (1999), "The economics and econometrics of active labor market programs", Handbook of Labor Economics, vol. 3, part A, O. Ashenfelter and D. Card (eds.), Amsterdam, North-Holland.

Johar, M. (2009), "The impact of the Indonesian health card program: a matching estimator approach", Journal of Health Economics, vol. 28, No. 1, Amsterdam, Elsevier.

Kozma R.B. (2008), "Comparative analysis of policies for ICT in education", International Handbook on Information Technology in Primary and Secondary Education, J. Voogt and G. Knezek (eds.), New York, Springer.

(ed.) (2003), Technology, Innovation and Educational Change: A Global Perspective, Eugene, International Society for Technology in Education.

Krüger, N. (2013), "Segregación social y desigualdad de logros educativos en Argentina", Archivos Analíticos de Políticas Educativas, vol. 21, No. 86 [online] http://epaa.asu.edu/ojs/ article/view/1352.

Lara, P. and J.M. Duart (2005), "Gestión de contenidos en el e-learning: acceso y uso de objetos de información como recurso estratégico", Revista de Universidad y Sociedad del Conocimiento, vol. 2, No. 2 [online] http://www.uoc.edu/ rusc/2/2/dt/esp/lara.pdf.

Llach, J., S. Montoya and F. Roldan (1999), Educación para todos, Buenos Aires, IERAL.

Machin, S., S. McNally and O. Silva (2006), "New technology in schools: is there a payoff?", IZA Discussion Paper, No. 2234 [online] http://ftp.iza.org/dp2234.pdf.

Maguire, C. and J. Zhang (2007), "Blended learning in the development context. Experience with GDLN in Asia-Pacific", Tokyo Development Learning Center [online] https://www. jointokyo.org/files/cms/news/pdf/Blended_Learning_in_the_ Development_Context_v1.pdf.

Muñoz, R. and J. Ortega (2014), “ ¿Tienen la banda ancha y las Tics un impacto positivo sobre el rendimiento escolar? Evidencia para Chile", paper presented at the 8th CPR LATAM Conference, Bogota.

Nannincini, T. (2007), "Simulation-based sensitivity analysis for matching estimators", Stata Journal, vol. 7, No. 3.

oECD (Organization for Economic Cooperation and Development) (2009), PISA Data Analysis Manual, Paris, oEcD Publishing.

Parshall, C.G. and others (2002), Practical Considerations in Computerbased Testing, New York, Springer.

Robinson, J.P, P. DiMaggio and E. Hargittai (2003), "New social survey perspectives on the digital divide", IT\&Society, vol. 1, No. 5.

Rodríguez, P., M. Nussbaum and L. Dombrovskaia (2013), "ICT for education: a conceptual framework for the sustainable adoption of technology enhanced learning environments in schools", Technology, Pedagogy and Education, vol. 21, No. 3, Taylor \& Francis.

Rosenbaum, P.R. and D.B. Rubin (1983), "The central role of the propensity score in observational studies for causal effects", Biometrika, vol. 70, No. 1, Oxford University Press. 
Santos, M. (2007), "Quality of education in Argentina: determinants and distribution using PISA 2000 test scores", Well-Being and Social Policy, vol. 3, No. 1.

Selwyn, N. (2004), "Reconsidering political and popular understandings of the digital divide", New Media \& Society, vol. 6, No. 3, SAGE.

Severín, E. and others (2011), Evaluación del programa "una laptop por niño" en Perú: resultados y perspectivas, Washington, D.C., Inter-American Development Bank (IDB).

SITEAL (Information System on Educational Trends in Latin America) (2014), Informe sobre tendencias sociales y educativas en América Latina 2014. Políticas TIC en los sistemas educativos de América Latina, Paris, United Nations Educational, Scientific and Cultural Organization (UNESCO)/ Organization of Ibero-American States for Education, Science and Culture [online] http://www.siteal. org/sites/default/files/siteal_informe_2014_politicas_tic.pdf.

Smith, J.A. and P.E. Todd (2005), "Does matching overcome LaLonde's critique of nonexperimental estimators?", Journal of Econometrics, vol. 125, No. 1-2, Amsterdam, Elsevier.

Spiezia, V. (2010), "Does computer use increase educational achievements? Student-level evidence from PISA", OECD Journal: Economic Studies, vol. 2010 [online] http://www1.oecd.org/ eco/labour/49849896.pdf.

Sprietsma, M. (2012), "Computers as pedagogical tools in Brazil: a pseudo-panel analysis", ZEW Discussion Papers, 07-040 [online] http://hdl.handle.net/10419/24604.

Sunkel, G. (2006), "Las tecnologías de la información y la comunicación (TIC) en la educación en América Latina. Una exploración de indicadores", Políticas Sociales series, No. 126 (LC/L.2638-P), Santiago, Economic Commission for Latin America and the Caribbean (ECLAC).

Sunkel, G. and D. Trucco (eds.) (2012), Las tecnologías digitales frente a los desafios de una Educación Inclusiva en América Latina: algunos casos de buenas prácticas (LC/L.3545), Santiago, United Nations.
(2010), "Nuevas tecnologías de la información y la comunicación para la educación en América Latina: riesgos y oportunidades", Políticas Sociales series, No. 167 (LC/L.3266-P), Santiago, Economic Commission for Latin America and the Caribbean (ECLAC).

Sunkel, G., D. Trucco and S. Möller (2011), "Aprender y enseñar con las tecnologías de la información y las comunicaciones (TIC) en América Latina. Potenciales beneficios", Políticas Sociales series, No. 169 (LC/L.3291-P), Santiago, Economic Commission for Latin America and the Caribbean (ECLAC).

Terzis, V. and A. Economides (2011), "The acceptance and use of computer based assessment", Computers \& Education, vol. 56, No. 4, Amsterdam, Elsevier.

UNESCO (United Nations Educational, Scientific and Cultural Organization) (2014), Reading in the Mobile Era. A Study of Mobile Reading in Developing Countries, Paris.

UNICEF (United Nations Children's Fund) (2014a), Las políticas TIC en los sistemas educativos de América Latina. Caso Brasil. Programa TIC y Educación Básica, Buenos Aires.

(2014b), Las políticas TIC en los sistemas educativos de América Latina. Caso Colombia. Programa TIC y Educación Básica, Buenos Aires.

(2013a), Las políticas TIC en los sistemas educativos de América Latina: caso argentino, Buenos Aires.

(2013b), Las políticas TIC en los sistemas educativos de América Latina. Caso Chile. Programa TIC y Educación Básica, Buenos Aires.

(2013c), Las políticas TIC en los sistemas educativos de América Latina. Caso Perú. Programa TIC y Educación Básica, Buenos Aires.

Witte, K.N. and N. Rogge (2014), "Does ICT matter for effectiveness and efficiency in mathematics education?", Computers \& Education, vol. 75, Amsterdam, Elsevier. 